\title{
WHY DID KOMPILASI HUKUM ISLAM SUCCEED WHILE ITS COUNTER LEGAL DRAFT FAILED? A Political Context and Legal Arguments of the Codification of Islamic Law for Religious Courts in Indonesia
}

\author{
Ahmad Imam Mawardi | UIN Sunan Ampel Surabaya - Indonesia \\ Achmad Kemal Riza | UIN Sunan Ampel Surabaya - Indonesia \\ Corresponding author: ai_mawardi@uinsby.ac.id
}

\begin{abstract}
Codification is a relatively new phenomenon in Islamic legal history. It intensified in the second half of the $20^{\text {th }}$ Century with the adoption of modern nation state by Muslims which eventually replaced the judicial function of madhhab. Thus, fiqh must transform into state-sanctioned law to remain relevant, as it is also an avenue to apply Islamic law in Indonesian Religious courts. This article aims at unveiling the process of codification of three statutes of Islamic family law, but with different result. While KHI was successfully enacted, CLD KHI failed after facing fierce opposition from Muslim community. The different fate of these two statutes is at least due to two aspects; time and content. KHI was enacted in 1991 when president Soeharto was courting Muslim groups for political supports in his New Order authoritarian regime. Its content is somewhat mirroring the 1974 Marriage Law. Drafts of CLD-KHI was circulated in 2004 after the fall of Soeharto in which free speech is a norm. Content wise, CLD KHI featured liberal interpretation of Islamic family law or even departure from it which is prone to opposition from various Muslim groups.
\end{abstract}

Keywords: Fiqh, Islamic law, codification, legislation, religious court

\section{Introduction}

As elsewhere in Muslim world, family law is always governed by Islamic law, albeit alterations. This is an exception because the norm is adoption of western based law by Muslims, especially those who 
experienced western colonization, such as Indonesia, India and Egypt. However, to become a valid legal reference for a court under nationstate arrangement, like many post World War II states are, these Islamic family law should be transformed from jurisprudence scattered in jurisprudence treatises of maddhab (Islamic school of law) into a form of code sanctioned by the state. ${ }^{1}$ In Muslim countries, this Islamic family law code then is often implemented by a special court named either Islamic court, Religious court or Sharia court. ${ }^{2}$

In Indonesia, the court is named as Pengadilan Agama, or literally translated as Religious Court. ${ }^{3}$ Although since of its incorporation into state control in the late period of Dutch administration in the late 19th Century until independence period in the 1970s the court was part of General Civil Court, nowadays it is an independent court with full authority. The independent Religious Court was acknowledged by the Act Number $14 / 1970$ on Judicial Authority which initially acknowledged the authority of Religious Court as equal to other three existing courts (General Civil Court, Military Court Marshall, and State Administration Courts). Act No. 7 of 1989 on the Authority of Religious Court which further elucidated the authority of Religious Court to assess and adjudicate cases brought to it, which is generally in the area of family law, ${ }^{4}$ Act No. 3/2006 on the Amendment of Act No. $7 / 1989$ by adding its authority to hear cases of Islamic banking and Act No. 50/2009 on the Second Amendment of Act No. 7/1989 which mainly deal with supervision and human resource of Religious Court.

A vital element in a court system is the existence of a legal code as a legal reference for every legal decision. It is impossible to achieve the certainty of law in the absence of a legal code. Moreover, the

\footnotetext{
1 Fazlur Rahman, "A Survey of Modernization of Muslim Family Law," International Journal of Middle East Studies, 11, 4 (July 1980), pp. 451-465.

2 Daniel S. Lev, the first western observer who studied the court in the 1960 s called the court as Islamic court. Read, Daniel S. Lev, Islamic Courts in Indonesia: A Study in the Political Bases of Legal Institutions (Berkeley Los Angeles and London: University of California Press, 1972), p. ix.

3 Ibid., ix-x.

${ }^{4}$ In accordance with the Compilation of the Islamic Laws as a legal reference of Religious Court, Religious Court is responsible and authorized to take cases in relation to unborn child, births, child custody, marriage, husband and wife's rights and obligations, marital community of property, divorces, parent custody, deaths, inheritance, and so forth.
} 
uncertainty of law shall result in a society's mistrust on legal institutions. For a period commencing from its establishment until 1974, Religious Court used to refer to the opinion of mainly Shafiite jurists set in several jurisprudence treatises known in Indonesia as kitab kuning (yellow books) in making their decisions. ${ }^{5}$ There are some shortcomings in using this kind of reference. The first concerns language barriers. Since those treatises are written in Arabic, a good command in Arabic is necessary for those involved in court, namely judge and lawyers. The second is that opinions of jurists on a case can be varied. The differences in the opinions found in Islamic jurisprudence treatises are likely to cause law uncertainty as long as Religious Court does not set the prevailing statement. The third is the lack of legal change in legal corpus of madhhab jurisprudence. Madhhab adherence means less or no opportunity of exercising ijtibad (legal interpretation), which in Islamic legal tradition is an effective avenue for legal change. As a result, it could not keep up with social dynamic of Muslim society.

In 1974, the uncertainty started to be cleared with the enactment of Act No. 1 on Marriage. The Act, according to Amir Syarifuddin, is legal material on marriage law for Religious Court. ${ }^{6}$ The Act, which was in discussion since as early as the 1950s, was the product of compromise between secular nationalists and Islamic groups. ${ }^{7}$ However, this act did not regulate several aspects of Islamic family law so that special regulation is a necessity. Thus, in 1991 the New Order government sanctioned the applicability of Compilation of Islamic Law which regulates Islamic law on marriage, inheritance, and bequest. The Compilation, though, by no means, followed consistently Shafii madhhab, since certain stipulations originated from opinions of other Sunni madhhab. This compilation, which was sanctioned in form of

5 There were 13 treatises of Islamic jurisprudence that were sanctioned by Ministry of Religious Affairs in 1958 to be used in Religious Court basic reference. They were: Hashiyah Al-Bajuri ala Fath al-Qarib, Fath Al-Mu'in, Sharqawi 'Ala al-Tabrir, Hashiyah Qalyubi wa Umayrah (Mahalli), Fath Al-Wabhab, Tubfah al-Mubtaj, Targhib Al-Mushtaq fi Abkami Masail at Talaq, Al-Qawanin Al-Shar'iyyah li Abl Al-Majalis Al-Hukmiyah wa alIftaiyah Li al-Sayyid Usman bin Yabya, Al-Qawanin Al-Syar'iyyah Li al-Sayyid Sadaqah Dablan, Syamsuri Li Al-Fara'idh, Buqbyah al-Mustarshidin, Al-Fiqh 'Ala Al-Mazabib AlArba'ah, and Mughni Al-Mubtaj.

6 Amir Syarifuddin, Hukum Perkawinan Islam di Indonesia (Jakarta: Kencana, 2006), p. 21.

7 Mark Cammack, Adriaan Bedner, and Stijn van Huis, "Democracy, Human Rights and Islamic Law in Post-Soeharto's Indonesia, New Middle Eastern Studies, 5 (2015), p. 7. 
President's instruction, was projected, and actually implemented, as legal reference for judges of Religious Court. The Reformation era after the collapse of Suharto's New Order Regime in 1998 has resulted in opening political doors closed during the new order era. Democratic processes and features were deployed in this era, including in legislating processes of aspects in Islamic law.

The commencement of the Reformation era marked the birth of several acts in the some aspects of Islamic laws through codification (taqnin), namely Act No. 38 of 1999 on the Management of Zakah, Act No. 17 of 1999 on the Providence of Hajj Pilgrimage, Act No. 10 of 1998 on Banking that amended changes the Law No. 7 of 1992 to accommodate the opening of sharia-complaint banks. In addition, to instigate peace in Aceh, in 1999 central government issued Act No. 44 about the Specialty of Aceh Province. The act stipulated the authority to govern certain aspects of law using Islamic law. In 2006, Mabkamah Syar'iyyah (Islamic court) was set up in Aceh to hear cases on certain Islamic law, including certain Islamic criminal law. Likewise, as central government granted certain autonomy for regions under Act No. 32/2004 on Regional Governance, plenty municipalities that had strong Muslim presence enacted bylaws on certain aspects of Islamic law under autonomy regulation, especially restriction on gambling, prostitution and liquor. ${ }^{8}$

In the area of Islamic family law, at least two additional proposals were put forward by the government (Ministry of Religious Affairs), namely CLD KHI in 2003 and RUU HMPA in 2010. CLD-KHI stands for Counter Legal Draft Kompilasi Hukum Islam which was projected to replace the 1991 Compilation. It was drafted by a team of gender mainstreaming set up by the Ministry of Religious Affairs. ${ }^{9}$ Thus this CLD-KHI was really prepared by Ministry of Religious Affairs. Considering the background of its authors, it is no surprise that the draft incorporated elements of gender equity in Islamic family law. They liberally interpreted primary religious sources to meet modern demands, especially gender equality. The gender elements,

\footnotetext{
8 On the overview of campaign for implementation of Islamic law in Reformation era please read Arskal Salim, Challenging the Secular State: The islamization of Law in Modern Indonesia (Hawai'i: University of Hawai'i Press, 2008) and Michael Buehler, The Politics of Shari'a Law: Islamist Activists and the State in Democratizing Indonesia (Cambridge: Cambridge University Press, 2016).

9 Cammack, Bedner, and van Huis, "Democracy, Human Rights and Islamic Law, p. 7
} 
though, became liability of the draft since many Muslim groups opposed which ceased its legislative processes. ${ }^{10}$ With similar fate, RUU HMPA also failed to pass the public test. RUU HMPA or publicly known as RUU Nikah Sirri was initially circulated in 2010.11 However, prompt controversy surrounding legal sanctions crippled it for further codification discussion. ${ }^{12}$

This study regards the phenomenal transform from figh law to positive law based on political and social perspectives, especially two drafts of Islamic family law, KHI and CLD-KHI. In order to find the answer to a question of what events and political contents and what social factors that brought the figh into a codification in Indonesia, it is necessary to obtain data that is comparable in terms of the political context and legal arguments between New Order era and post-New Order era.

\section{Transformation of Fiqh To Code in Islamic Legal History}

The early development of Islamic law, up to $9^{\text {th }}$ century CE, shows that the form of Islamic law are Islamic legal opinions of mujtabid and Islamic non-binding legal opinion (fatwas) of independent mufti (fatwa giver) as well as court verdict (qada) by Muslim judges. Everyone has the right to follow which view considered as the representation of the truth. People are not necessary to adhere to any schools. ${ }^{13}$ The positive side is that it is the part of the freedom of speech, but the negative side is the absence of the legal certainty that will be used as the official reference to judge a certain dispute.

When the society transforms to be more complex and the Islamic world expanded, legal problems that have the context of space and

10 Euis Nurlaelawati, Modernization, Tradition and Identity: The Kompilasi Hukum Islam and Legal Practice in the Indonesian Religious Courts (Amsterdam: ICAS/Amsterdam University Press, 2010), p. 127.

11 “Lika-liku Draf RUU Nikah Siri Hingga Jadi Misterius," https://news.detik.com/berita/d-1303144/lika-liku-draf-ruu-nikah-siri-hingga-jadi-misterius/komentar, 19th of February 2010 (accessed on 7 January 2019)

12 "Edy Supriatna Sjafei, Kontroversi Pidana Pelaku Nikah Siri," https://megapolitan.kompas.com/read/2010/02/24/00141637/kontroversi.pidana.pe laku.nikah.siri?page $=$ all, 24 February $2010($ accessed on 7 January 2019)

13 Historians of Islamic law designate this period as formative period of Islamic law. Read for instance, Wael B. Hallaq. A History of Islamic Legal Theories: An Introduction to Sunni Usul al-fiqh (Cambridge: Cambridge University Press, 1997), especially Chapter I, pp. 1-35. 
time are definitely varied. Legal certainty is significant to avoid the legal confusion based on various views causing inescapable conflict. ${ }^{14}$ The role of madhhab and its jurists was crucial in maintaining somewhat legal order in Muslim world. The jurists of maddhab acted as qadi (judge) in Muslim courts providing judicial role for Muslim polities across the Muslim world for centuries. They employed legal corpus of madhhab when delivering verdicts in courts. ${ }^{15}$ Therefore, in a region where Hanafi madhhab prevailed, such as Turkey during Ottoman empire, then Hanafi jurists would become judges in court based on opinions of Hanafi madhhab found in legal corpus in Hanafi Jurisprudence. For Southeast Asia, including Indonesia, Shafii madhbab was adopted, so that Shafi'I judges took the role of judiciary using legal corpus of Shafii jurisprudence. However, when Western powers started to penetrate Muslim world in the $18^{\text {th }}$ Century onwards, this judicial arrangement was deemed insufficient. Maddhab-based judiciary was considered ineffective and Islamic law was thought to have been out of date. Therefore, to fix the problem, codification or legislation was proposed with all of its consequence. ${ }^{16}$

In the history of Islamic law development, this tradition of codification and legislation is surprisingly absent although efforts had been done to do that. This case is in line with the historical fact that

\footnotetext{
14 It is always stated that law is a definitive conception from the characteristic of law and social function from the regulation by law. Three conceptions that should be paid attention to: (a) law is a set of general prescriptive sentences forming the part of law system; (b) prescriptive sentence becomes a law is not because of the quality of the sentence content but the quality of source, where the authority of law is identified by the authority of legislative power of certain country; and (c) the goal of law is to guarantee freedom, and the similarity of degree becoming the main requirement of all individual's enjoyment, justice, and social prosperity. Hence, the absence of codified law will cause a conflict in the society.

15 Wael B. Hallaq. Authority, Continuity and Change in Islamic Law (Cambridge: Cambridge University Press, 2001), pp. 80-81

16 This codification tradition, genealogically, can be traced until the utilitarianism philosophy of Jeremy Bentham. Bentham views that to maximally reach the benefit for people in the form of reaching the happiness and denying the misery, we need a united reference namely civil code explaining the right and obligation, pebal code that explains the law violence and law sanction, as well as constitutional code containing the law related to the setting of social organization. This philosophical view of Jeremy Bentham regarding codification can be read in Philip Schofield and Jonathan Harris (eds), The Collected Works of Jeremy Bentham: Legislator of the World: Writings on Codification, Law and Education (Oxford: Clarendon Press, 1988).
} 
unification, compilation, and codification have become the thought of judges at the early period of Islam. Ibn al-Muqaffa' (d. 139/756), for example, has suggested to al-Mansur (754-775 CE), a caliphate of Abbasid Dynasty) to "review the doctrines or diverse teachings, codify and legislate the decisions directing to the unification and make the regulation or law as something that binds the judges." 17 For this case, al-Muqaffa' recommended to al-Mansur to use al-Muwatta' a book written by Malik ibn Anas (d. 795 CE) as the work of standard law that can be used in all regions. This suggestion was then delivered by alMansur to Malik ibn Anas when they met during hajj season in Medina. ${ }^{18}$ Malik ibn Anas refused the idea arguing that people should not be forced to take opinions of one expert of Islamic law (faqib) because such thoughts are possibly wrong and imperfect. ${ }^{19}$

Although attempts to introduce statutory legislation were recorded, ${ }^{20}$ the first Islamic codified law only took place during the late period of Ottoman Empire, when the period of Tanzimat (18391879), the government successfully codified Islamic law provisions derived from Hanafi jurisprudence and compiled in a 1869 code. It entitled Majallah al-Aḅkam al-'Adliyah (Mecelle) which covers contracts, torts, and some principles of civil procedure. ${ }^{21}$ Likewise, Aurangzeb

17 The historical fact of this thing is discussed by Joseph Schacht in his book that makes his name popular in the study of Islamic law, see Joseph Schacht, Introduction to Islamic Law (Oxford: Clarendon Press, 1986), p. 55. See also N. J. Coulson, A History of Islamic Law (Edinburgh: Edinburgh University Press, 1964), p. 52; Compare to the explanation of Marshal G. S. Hudgson, The Venture of Islam (Chicago: The University of Chicago Press, 1977), vol. 1, pp. 284-5.

18 Mazheruddin Siddiq, the Introduction of Muwatta' Imam Malik book, the translation and note were done by Muhamad Rahimuddin (New Delhi: Bhavan Book, 1989), pp. iv-v.

19 Critical review of this historical fact can be read in Patricia Crone and Martin Hinds, God's Caliph: Religious Authority in the First Century of Islam (Cambridge: Cambridge University Press, 1986), p. 86-7; Joseph Schacht, "Foreign Elements in the Ancient Islamic Law," Journal of Comparative Legislation and International Law 32 (1950), p. 17; Ann Elizabeth Mayer, "The Shari'ah: A Methodology or a Body of Substantive Rules," Nicholas Heer (ed.), Islamic Law and Jurisprudence: Studies in Honor of Farbat J. Ziadeh (London: University of Washington Press, 1990), p. 179.

20 Muhammad Hashim Kamali, Principles of Islamic Jurisprudence (Cambridge: Islamic Text Society, 1991), p. xvii.

21 See S.S. Onar, "The Majallah," Majid Khaddury and Herbert J. Liebesny (eds), Law in the Middle East: Origin and Development of Islamic Law (Washington D.C.: The Middle East Institute, 1955), p. 292-306. 
Alamgir (d. 1707) of Mughal empire ordered the a compilation of fatwas known as Fatawa al-Alamgiriya or al-Fatâwa al-Hindiyab22 as the effort to do unification of law regulations. In early $20^{\text {th }}$ century, Code Morand or Avan-Projet de Code du Droit Musulman Algerien published in 1916 in Algeria had a similar purpose. ${ }^{23}$

Codification of Islamic law, especially in the area of family law, escalated alongside the creation of modern states by Muslims post World War II. ${ }^{4}$ The development of social structure from traditional to modern followed by the increase in complexity of the pattern of social relation has demanded the Islamic law as one of the living laws in the society that evolve from uncodified to codified form. ${ }^{25}$ In the modern country, it is clear that the law shift from one step to another step toward the final step is called rule of law. In Europe, for example, the law transformation from traditional and conventional toward the liberal and constitutional countries started since the early $19^{\text {th }}$ century, and then it still moves to the second phase which is the law attachment to the legislative power so that it has a binding power with the good and regular set of administration, and then arrives totally in the third step that is rule of law. In this last stage, the fundamental rights of people will be guaranteed and fairly applied. This is the last goal of that codification tradition. ${ }^{26}$

22 See Shaikh Nizam and 'Ulama' al-Hind al-'Alam, al-Fatawa al-'Alamkiriyah alMa'rufah bi al-Fatawa al-Hindiyyah, edited by Ghulam Nabi Tunsawi (Kuitiyah: Maktabah Majidiyah, 1983).

23 See Schacht, Introduction to Islamic Law, pp. 94-8.

24 Fazlur Rahman, "A Survey of Modernization of Muslim Family Law," International Journal of Middle East Studies, 11, 4 (July 1980), pp. 451-465.

25 The most well-known scholar of evolution law from primitive society to modern society is Sir Henry Sumner Maine (1822-1888). In his book entitled Ancient Law published in 1861 page 170, he firmly stated the shift of status to contract. The theory of this Status-Contract is very famous in the study of law sociology. The early 19th century was exactly established by law scholars as the early movement to modern law with codification. This case is the direct effect from renewal movement in the age of enlightment. See, Nils Jansen, The Making of Legal Authority (Oxford: Oxford University Press, 2010), p. 16.

26 An interesting discussion of philosophical dimension of this rule of law can be read in Kyle A. Scott, "A Platonic Critique of Codification," Journal Jurisprudence, 159 (2009). In his view, the rule of law is a must. How is the law arranged, interpreted, and executed is a unity of the realization of what is called a fair law becoming the substance of the rule of law. 
The process of law development to the legislation and codification usually runs in the relatively late time interval compared to the speed of social change. This phenomenon happens to the legislation and codification in some Islamic countries such as Syria, Tunisia, Morocco, Iraq, and Pakistan ${ }^{27}$, as well as in Indonesia with limited scope of the law of family matters.

\section{Transformation From Fiqh To Code in Indonesia}

In the context of the history of Indonesia, since the colonial era, Dutch administration had made some codifications like the compendiums as the reference of Islamic law application, exclusively concerning family law. ${ }^{28}$ In the period of the Old Order Regime (1945-1966), there were some acts and regulations reflecting the entering of Islamic law in national law material like the 1946 Act on marriage registration. In the period of the New Order Regime (19661998), there were some acts and government regulations with Islamic law nuance such as the Marriage Act No. 1/1974, the Government Regulation no. $7 / 1975$ on the Implementation of the Act 1/1974, the Government Regulation on the Endowment of Land Ownership no. 28/ 1977, the Act no. 7/1989 on the Act of Religious Judicature Court, the Regulation of the Ministry of Religion no. 2/1990 on the guideline of marriage in an Islamic way, and the others. Seeing such trend, especially the observation on the Act of Religious Judicature No. 7/1989 and the Compilation of Islamic Law 1991, an observer contemplated whether the phenomenon was Islamization of Indonesia

27 Regarding the development of law in these countries can be seen in Yasir Billoo, "Change and Authority in Islamic Law: The Islamic Law of Inheritance in Modern Muslim States," ExpressO Preprint Series, 2003, paper 12. It can be accessed in http://law.bepress.com/expresso/eps.12; see also as the main comparator, J.N.D. Anderson, Islamic Law in the Modern World (New York: New York University Press, 1959).

28 See, for example, Compendium Freijer that was used by the court of VOC to judge the problem of Islamic marriage and inheritance (Resolutie der Indisch Regering, dated 25 th of May 1760); Cirbonsch Recbboek (Law Book of Cirebon in 1757-1765); Compendium der Voornaamste Javaanisch Wetten Naunkeuring Getrokeen uit het Mohammedaansch Wetboek Mogharraer that was arranged in Semarang in 1750 and Compendium Inlandsch Wetten bij de Hoven van Bone en Goa that was applied in South Sulawesi. Read, Mohammad Daud Ali, Asas-asas Hukum Islam (Jakarta: Rajawali Press, 1990), pp. 213-4. 
or Indonesianization of Islam. ${ }^{29}$ The following discussion will exclusively scrutinize Religious Courts and three legal texts on Islamic family law that circulated during the New Order period and after.

\section{Historical Sketch of Legal Reference of Religious Court}

It cannot be denied that wherever the form of judiciary system starts from the conventional and traditional form. Initially, the method of dispute resolution is by inviting mediator agreed together. It is usually from the respected social figure. This case is usually applied to the customs dispute resolution. In the dispute related to religious affairs, the religious figure regarded the most pious and commanding one would be the reference to solve people's problem. ${ }^{30}$

In the context of Islamic history of Indonesia, in the early period of the emergence of Islamic kingdoms, religious authority integrated with political authority. Sultan, king, or malik have a very enormous authority. The legal references represented the belief (madhbab) of the king, including those utilized in courts of justice. ${ }^{31}$ Since the early period of the development of Islam in the archipelago, the prevailing madhhab was Shafi'I madhhab. ${ }^{32}$ This case became the reason de 'Etre,

29 Mark Cammack, “Indonesia's 1989 Religious Judicature Act: Islamization of Indonesia or Indonesianization of Islam?," Arskal Salim and Azyumardi Azra (eds), Shari'ah and Politics in Modern Indonesia (Singapore: ISEAS, 2003).

30 If in a country, there is a state court, the traditional society usually has the tendency to settle their problems based on the customs or tradition that become the form of informal court of society. This case is applied in all traditional people. See Marc Galanter, "Justice in Many Rooms: Courts, Private Ordering and Indigenous Law," Journal of Legal Pluralism 19 (1981), p. 3.

31 For instance, during the reign of Sultan Agung of Mataram, Siti Inggil court which was originally located in the palace moved to court yard of grand mosque, therefore, the court was renamed as Surambi court. The transformation, though brought about some modifications, such as kadhi/penghulu replaced king as judge, all cases called as kisas regardless of classification, and single judge was replaced by collegial judgeship, and all rulings ought to be authorized by king before taking effect. Read, R. Tresna, Peradilan di Indonesia Dari Abad Ke Abad (Jakarta: Pradnya Paramita, 1978), pp. 17-18.

32 Carool Kersten states that in the $14^{\text {th }}$ Century Shafii madhhab was adopted by Sultanate of Samudra Pasai in Northern tip of Sumatera based on reports by Ibn Battuta. Read, Carool Kersten, A History of Islam in Indonesia: Unity in Diversity (Edinburgh: Edinburgh University Press, 2017), p. 11. Martin van Bruinessen suggests that further footing of Shafii madhhab was due to, among other things, the learning of Indonesian students under Kurdish Shafiite scholars in Hijaz in the 17th Century Hijaz (Mecca and Medina) onwards. Read, Martin van Bruinessen, "Kurdish 'Ulama and their Indonesian disciples", Les annals de l'autre Islam 5 (1998), p. 88. 
why the reference of the religious court was affiliated to madhbab Shafi'I. This was done with several accommodation to local custom, such as the authorization of court decision by the king and the use of collegial judgeship, instead of individual. ${ }^{33}$ Certainly, local law, which later was dubbed as adat, was also influential, especially in the area of marital property and inheritance. ${ }^{34}$ In fact, it was in mainly these family matters that religious courts were operational, ${ }^{35}$ because these matters related very dearly to Muslims' religiosity. A failure to ascertain validity of marriage according to Islamic teaching might fall into adultery, which is major sin in Islam. ${ }^{36}$ When the Dutch came to Indonesia starting in the early eighteenth century, they let indigenous people used their indigenous law to govern in courts. With the assumption that Islamic law governed the already Islamized indigenous people, the Dutch East Indies Company supplied translation of some treatises of Shafii school of law, namely Matn al-Ghayah wa al-Taqrib, alTabrir fi sharh Tubfah al-Tullab, and Kifayah al-Ahyar fi bill kalam Abi Shuja' to be used in court, however with mixed result. ${ }^{37}$ Since 1882 onwards, however, religious courts (priestraad and later penghuluraad) were incorporated into Dutch judicial system and only authorized in hearing cases in family law matters, with minor status since it was located under auspices of Civil Courts. ${ }^{38}$

The period of independence (post-revolutionary) showed drastic administrative shift of Religious Court. While It was under auspices of Civil Court during pre-revolutionary period, and therefore, administered by Ministry of Justice, the newly-established Ministry of Religious Affairs took over Religious Court in 1946 on the basis that this ministry was in charge of religious affairs, including religious judiciary. ${ }^{39}$ Nevertheless, efforts to abolish religious court altogether by incorporating it into civil courts still were still in minds of secular

\footnotetext{
33 Tresna, Peradilan di Indonesia, pp. 17-18

34 Ratno Lukito, Pergumulan antara Hukum Islam dan Adat di Indonesia (Jakarta: INIS, 1998), pp. 82-92.

35 Lev, Islamic Courts in Indonesia, p. 11

36 Idri, "Religious Court In Indonesia: History and Prospect," Journal of Indonesian Islam, 3, 2 (December 2009), p. 298.

37 Andi Tahir Hamid, Beberapa Hal Baru Tentang Peradilan Agama dan Bidangnya (Jakarta: Sinar Grafika, 1996), p. 3-4.

38 Tresna, Peradilan di Indonesia, p. 102.

39 Lev, Islamic Courts in Indonesia, p. 63.
} 
nationalists within the Regime as Ministry of Religious Affairs fought its best using its limited power and influence to maintain and manage Religious Court.

In 1958, the Ministry of Religious Affairs, through the Letter of Religious Judiciary Bureau No. 8/1/735, dated $18^{\text {th }}$ of February 1958 as the implementation of the Government Regulation No. 45/1957 on the Establishment of Mabkamab Syar'iyah (Religious Court) outside of Java and Madura, issued a list of 13 jurisprudence treatises for legal reference by judges of Religious Courts namely Bughyat al-Mustarshidin by Ḥusayn al-Ba'lāwi, al-Faräid by al-Shamsūiri, Fatḥ al-Mu'in by Zayn

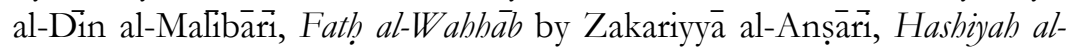
bajuri 'ala fath al-Qarib by al-Bajūīi, Mughni al-Muḅtāj by al-Sharbini, Qawāin al-Shar'iyyah by Sayyid 'Uthmān in Yahyā, Qawāin al-Shar'iyyah by Sayyid 'Abdullah ibn Șadaqah Dakhlān, Sharḅ Kanz al-Rāghibīn karya al-Qalyübi and 'Umayrah, Sharh al-Tahrir by al-Sharqāwi, Tuhfah alMuḅtāj by Ibn Hajar al-Haytāmi, Targhì al-Mushtāq by Ibn Hajar alHaytāmi, and al-Fiqh 'Alä Madhähib al-Arba'ah by al-Jaziri. ${ }^{40}$

In practice, these Islamic jurisprudence treatises had been utilized by judges in their courtrooms. Thus, this letter was a mere confirmation of the practice, and at the same time a guide for judges. The use of the treatises was simply the lack of a code that dealing with Islamic family law, yet. Such books mentioned above are the corpus of classical figh following madhhab Shafi'i except the last treatise that is a relatively modern treatise (written by 'Abd al-Rahman bin Muhammad 'Awad al-Jaziri (1882-1941) that compares four Sunni madhhabs namely Hanafi, Maliki, Shafi'i, and Hanbali. As treatises of classical Islamic jurisprudence $(f i q h)$, the arrangement is similar the arrangement of general figh books that have analytical descriptive which are not systematic as legal codes of modern court institution.

This move, though, was not sufficient if the court still maintain aspiration to become a proper court in a modern state like Indonesia. There should be a code on family law sanctioned by the state that would govern family law in Indonesia. Indeed, the aspiration to have a code on family law was not only concern of Ministry of Religious Affairs and judges of Religious Court because ministry of Justice and the legislature since the 1950s also thought the same. However, series

40 Amrullah Ahmad, et.al, Dimensi Hukum Islam dalam Sistem Hukum Nasional: mengenang 65 th. Prof. Dr. H. Busthanul Arifin, SH (Jakarta: Gema Insani Press, 1996), p. 11. 
of attempts to pass the bill of marriage law in the legislature failed to gain agreement. Secular nationalists represented by Ministry of Justice and Islamic groups represented by Ministry of Religious Affairs clearly had different views pertaining marriage law as well as its implementing courts of justice. While the formers demanded a secular family law implemented by Civil Court, the latter insisted Islamic family law with Religious Court as the court of justice.

In 1974, during the heyday of the New Order regime with its military backing, the fate of family law was passed with the enactment of Act No. 1 on Marriage. The Act was the product of compromise between secular nationalists and Islamic groups. Initially, the bill was drafted by secular nationalists in the Ministry of Justice with strong assistance from CSIS (Center for Strategic and International Studies), a think tank to the Suharto Regime founded and run by minority Christians and Catholics. ${ }^{41}$ It was very secular in nature; it only acknowledged civil marriage, equal right between husband and wife pertaining divorce, heavy restriction on polygamy, acknowledgement of adoption, and so forth. It was designed to apply all citizens and therefore assigned to the civil courts. Thus, it also meant that if this bill is passed, the fate of Religious Court would cease. It was a plan of throwing two birds with one stone scenario. However, it faced fierce opposition from Islamic groups since the proposal was considered very "un-Islamic". Islamic groups, regardless of their persuasions, for once rallied together to refuse the bill, both inside the legislature and on the street. This made Suharto, who himself was a secular nationalist, came to terms with potential political risk of pressing on this move. He then ordered his backings in the legislature, especially the military faction, to accommodate demands of Islamic groups. ${ }^{42}$ A sort of compromise then was achieved by revising aspects of the proposal to satisfy both apposing groups. Some proposals of the secular nationalists remained, such as marriage registration, setting marital age, limitation of polygyny, joint marital property, and arrangement of divorce procedure. Still, the Act marked a greater inclusion of Islamic law into law on marriage because many stipulations in the Act reflected

\footnotetext{
41 Cammack, Bedner, and van Huis, "Democracy, Human Rights and Islamic Law, p. 7

42 Nurlaelawati, Modernization, Tradition and Identity, p. 69.
} 
the provision of Islamic family law. ${ }^{43}$ For instance, the Act defines marriage as a religious union. It also acknowledges husbands as head of family, proving their superiority over wives. The Act is applicable for all citizens regardless of religions. According to Amir Syarifuddin, it is legal material on marriage law for Muslims referring their marital disputes to Religious Court. ${ }^{44}$ For non-Muslims who suffered similar domestic issues, they bring their cases to Civil Court, and this Act is also applicable.

For legal aspects alien to traditional Islamic law, innovative reasoning was employed as a means of their justification. Eventually, this local reasoning for making sense of legal change was dubbed as Indonesian madhhab or Indonesian fiqh. ${ }^{45}$ An effort for this kind was shown by Sajuti Thalib when making sense marital property. He argues that marital property is part of shirkah (joint-venture) between husband and wife, which would be divided equally upon separation. ${ }^{46}$ Similarly, Ahmad Rofiq justifies marriage registration which is not discussed in traditional Islamic jurisprudence by making analogy to trading accounting which is clearly regulated in the Holy Quran. ${ }^{47}$ Others also consider ta'liq al-talaq (conditions that enable wives to initiate divorce) as a means for wives in initiating judicial divorce on certain grounds, something that traditional Islamic jurisprudence is silent. ${ }^{48}$

\section{A Political context and legal discourse of the 1991 Compilation of Islamic Law}

Although this 1974 Marriage Act has been implemented, judges of religious court needed more reference for them in dealing with legal process. Moreover, as the Act No. 71989 on Religious Judicature was

\footnotetext{
43 Cammack, Bedner, and van Huis, "Democracy, Human Rights and Islamic Law, p. 7

${ }_{44}$ Amir Syarifuddin, Hukum Perkawinan Islam di Indonesia (Jakarta: Kencana, 2006), p. 21.

45 Lukito, Pergumulan antara Hukum Islam dan Adat, pp. 75-77. Read also MB. Hooker, Indonesian Islam: Social Change Through Contemporary Fatawa (Crows Nest: Allen and Unwin, 2003), pp. 33-35.

46 Sayuti Thalib, Hukum Kekeluargaan Indonesia: berlaku Untuk Umat Islam (Jakarta: UI Press, 1986), pp. 79-92.

47 Ahmad Rofiq, Hukum Islam di Indonesia (Jakarta: RajaGrafindo Persada, 1995), pp. 118-121.

48 Lukito, Pergumulan antara Hukum Islam dan Adat, pp. 77-81.
} 
passed, it listed aspects of legal authority of Religious Courts, namely; marriage, inheritance, will and testament (wasiat), bequest (bibab), and property endowment (waqf). While the 1974 Marriage Act concerns marriage, it does not stipulate details of Islamic family law, such as arrangements about marriage proposal (khitbah), dowry (mahr), marrying pregnant women, reconciliation (riju), mourning period, and so forth. In addition, the 1974 Marriage Act did not stipulate inheritance, will and testament, bequest and property endowment. Inheritance and Islamic bequest (waqf), both of which are legal domain of Religious Court if the litigants are Muslims. As such, as early as 1985, the government, especially Supreme Court and Ministry of Religious Affairs had started the collaboration to prepare what was to be the code specifically for Religious Court. ${ }^{49}$

The legislation process of Islamic family code coincided with two different developments concerning the relationship between Islam and the New Order Regime. Actually, the regime was generous enough to support Islamic causes as long as they did not concern politics. New mosques and prayer rooms, national Quranic competition (MTQ), establishment of Indonesian Council of Ulama (MUI), proliferation and modernization of Islamic education from elementary Islamic schools to tertiary Islamic educations were sponsored by the regime. ${ }^{50}$ Similarly, a handful of devout Muslims were admitted into bureaucracy in this decade. ${ }^{51}$ Gradually, there was shift of attitude among Muslims towards the regime. While in the 1970s they were disappointed with the curtailment of political participation launched by the regime for the sake of economic development, many Muslims detached themselves from the regime and all its modernizing programs.

However, in the1980s, the atmosphere were different as many modernist Muslims joined the regime in all of its fronts, especially in bureaucracy, political party (Golkar), or even non-government organizations. ${ }^{52}$ There was also a phenomenon of growing popularity

49 Barmawi Mukri, "Kedudukan dan Peranan Kompilasi Hukum Islam dalam Sitem Hukum Nasional," Jurnal Hukum 8, 17 (June 2001), p. 26.

50 Robert W. Hefner, "Islam, State, and Civil Society: ICMI and the Struggle for the Indonesian Middle Class," Indonesia 56 (Oct., 1993), pp. 1-35.

51 Robert W. Hefner, Civil Islam: Muslim and Democratization in Indonesia (Princeton: Princeton University Press, 2000), p. 131.

52 Fachry Ali and bachtiar Effendi, Merambah Jalan Baru Islam Rekonstruksi Pemikiran Islam Indonesia Masa Orde Baru (Bandung: Mizan, 1986), pp. 154-166. 
of Islam among urban people, who were born from abangan families, starting from the 1980s, especially in big cities like Jakarta, Bandung, Yogyakarta, and Malang. They were successful in their lives but longed for filling their lives with something more meaningful than just material fulfilment. They were professionals, and often middle and high-rank bureaucrats. These middle class people started to seriously embrace Islam and implement it in their lives. ${ }^{53}$ This trend continued with the emergence of young Muslims, usually studied exact sciences (not in Islamic studies faculties) in state universities, that studied Islam on their own way. They were called as the new santri and their movement was called Tarbiyah. The outlook of Islam they embrace were similar to al-Ikhwan al-Muslimun of Egypt. ${ }^{54}$

The formal representation of this group of new Muslims came into being with the establishment of Association of Indonesian Muslim Intellectuals (ICMI - Ikatan Cendekiawan Muslim Indonesia) on $7^{\text {th }}$ of December 1990 under patronage of Baharuddin Jusuf Habibie, then was the Ministry of Research and Technology, a close friend to President Soeharto. In fact, its establishment was sponsored by this president with him present at inaugural ceremony by beating large drum, a drum beaten in mosques signaling the prayer times, one day earlier. The establishment of a national-scale Islamic association with the blessing of the top leadership of the New Order Regime was unheard off in the previous decades, but Soeharto needed new political supports as a couple years before his relationship with the military deteriorated as a certain high officers started to challenge his authority. ${ }^{55}$ In subsequence, several pro-Islam programs were launched by the regime, for instance, the opening sharia-based bank, the lifting of jilbab scarf prohibition for students, and abolition of the state lottery. ${ }^{56}$

All of these contexts helped the relatively smooth sanction of the Compilation through Presidential instruction. The has been a degree of "greenization", the process of becoming more devout Muslims among

\footnotetext{
53 Hefner, Islam, State, and Civil Society, pp. 1-35.

54 Read for instance, Yon Mahmudi, Islamising Indonesia: the rise of Jemaab Tarbiyah and the Prosperous Justice Party (PKS) (Canberra: ANU E-Press, 2008) especially Chapter 1: the Emergence of the New Santri in Indonesia, pp. 21-50.

55 Hefner, Civil Islam, p. 125.

56 Ibrahim Abu Rabi' (ed.), Blackwell Companion to Contemporary Islamic Thought (Malden, Oxford and Carlton: Blackwell Publishing, 2006). p. 477.
} 
secular nationalists, in the bureaucracy. Likewise, there were a handful of modernist Muslims holding key position as well, including in judiciary. Supreme Court, which were traditionally stronghold of secular nationalists then became "less hostile" to Islamic agendas and causes. This is manifested in a supreme justice named Bustanul Arifin, a modernist Muslim who was chairman of the Special Chamber in the Supreme Court treating judicial appeals from religious courts at the time. ${ }^{57}$ He was a judge of Religious Court by career and had a Muslim modernist. His role was not only instrumental in the creation of the Compilation but also the 1989 Religious Judicature Act. At the Ministry of Religious Affairs, the role of the minister himself, at the time was Munawir Sjadzali was also instrumental in securing the project. He himself had the mission to re-actualize Islamic law, especially in the area of inheritance. ${ }^{58}$

After Suharto was tamed, the Committee dealt with the subsequent potential obstacles, the ulama. It was done by reaching them out to discussing the material of the upcoming code. No less than 186 ulama from all persuasions (traditional, modernist, and academics) were invited for the purpose. ${ }^{59}$ They were once also invited to attend a workshop to formulate the draft of KHI on 2 to 5 of February 1988 to discuss the draft of the compilation from cover to cover to seal their approval. In addition, to make sure that the material of the Compilation was Islamic, about 39 Islamic jurisprudence treatises were studied by scholars of Islamic jurisprudence of seven State Islamic Institutes (IAIN - Institute Agama Islam Negeri) across the country. Similar to modernization of Islamic family law projects elsewhere in Muslim countries, the effort done by not only studying the prevalent maddhab of the people, in this case is Shafii jurisprudence, but also

57 For further account, please read Nurlaelawati, Modernization, Tradition and Identity, pp. 80-81

58 His idea of equal portion between men and women in inheritance was actually floored for discussion by the ulama during the formulation of the Compilation, although it was eventually rejected. Ibid., pp. 81-83

59 Some notable traditional ulama included Anwar Musaddad, Ali Ma'shum, MA. Sahal Mahfudh, Nadjib Wahab, and Sanusi Baco. Similarly, among several well-reputed modernist ulama were Ahmad Azhar Basyir, AR fachruddin, MO. Bafadhal, and Rahmat Djatnika. They were invited through 10 (ten) High Religious Courts close by, namely Banjarmasin, Padang, Palembang, Makassar and Surabaya. Read, Busthanul Arifin, Pelembagaan Hukum Islam di Indonesia: Akar Sejarah, Hambatan dan Prospeknya (Jakarta: Gema Insani Press, 1996), p. 155-161. 
electively scrutinizing jurisprudence treatises of other three Sunni madhhabs and beyond. ${ }^{60}$ The fact that there were 39 jurisprudence treatises from various schools of law referred in the project ${ }^{61}$ is an indication that the development of Islamic law in Indonesia is significantly dynamic following the social need. The views of several madhbab that are possibly appropriate to be a reference are taken to be the articles in the Compilation. The last but not the least was comparative studies to Egypt, Morocco and Turkey which had successfully implemented family code based on, more or less, Islamic jurisprudence by supplanting it into modern judiciary. ${ }^{62}$

Considering avenues taken on by the committee of the Compilation, it is understandable that it virtually did not meet any criticism. All potential barriers, namely the regime (read: President Suharto), judiciary, bureaucracy, and the ulama all were involved, and therefore approved it, in one way or another. The legislature somewhat was circumvented since the Compilation was sanctioned in form of Presidential Instruction which needed no further hearing in the legislature. However, the main success of behind its smooth enactment is actually its confessional stance to Islamic jurisprudence. All material of the compilation originates from Islamic jurisprudence as mirrored by its sources, albeit in eclectic manner breaching madhhab boundaries in some points. For instance, the decision to allow marry a pregnant woman (out of wedlock) only by the person who caused the pregnancy was sought from Maliki madhhab, not from Shafii madhbab which allowed any person marrying that pregnant woman.

Even if a breach from the doctrines of four Sunni madhhabs was required, such as on the issue of restricting polygyny, a form of reinterpretation of sacred sources was applied. The most used authority

60 The usual methods of modernization of Islamic law through codification are exercising ijtihād, by the liberal use of tahayyur (selection of legal opinions) and talfiq as well as by the generous employment of weak opinions of madhhab. In addition, the expansion of codified Islamic law, and the extension of siyasah shar'iyyah (rulers' authority to make regulations on religious affairs). Read JND. Anderson, "The Significance of Islamic Law in the World Today," The American Journal of Comparative Law 9, 2 (Spring 1960), pp. 192-4.

${ }^{61}$ Among the treatises are Bada'i al-Sana'i fi tartib al-Shara'i by al-Kasani al-Hanafi, Bulghah al-Salik by Ahmad al-Sawi al-Maliki, I'anah al-Talibin by Said Bakri Shata alShafii, Kashaf al-Qina by al-Bahuti al-Hanbali, al-Muhalla by Ibn Hazm al-Dhahiri, and Fiqh al-Sunnah by Said Sabiq.

${ }^{62}$ Nurlaelawati, Modernization, Tradition and Identity, p. 87. 
on the matter is Muhammad Abduh's interpretation on the Quran Chapter 4:3, which is the main proof for the permissibility of polygyny, arguing that such practice is only permissible for those in need with severe requirements. His conclusion was reached after combining the verse 3 and 129 of the Chapter $4 .{ }^{63}$ Likewise, the consent of both bride and groom, which is stated clearly in the Compilation, was justified by reinterpreting a prophetic tradition which actually speaks about consent of bride. ${ }^{64}$ Interestingly, this hadith was also used to justify consent of wife upon reconciliation act (riju) by the husband. Such consent is deemed contradictory to traditional Islamic jurisprudence since ruju' is a prerogative right of husbands, which does not need approval of wife. ${ }^{65}$

In addition, it should be remembered that the Compilation came into being to complement the 1974 marriage Act. Thus, the Compilation in many ways only justified the already implemented stipulations of the 1974 marriage Act. ${ }^{66}$ Therefore, the actual battle was fought in the early 1970s when the bill of marriage was on the table. The debatable issues in the 1974 marriage Act, such as marital age, marriage registration, restriction of polygyny, and conditions as well as procedure of divorce were considered finish and accepted by Muslim community. At least, Muslims have their own way to circumvent the stipulations they deemed contradictory to their religious conviction. For instance, they might still register marriage but not deeming it as compulsory or done later after religious ceremony. Likewise, although they pay attention to court hearing for divorce, they still subscribe to traditional Islamic jurisprudence by acknowledging talaq (repudiation) outside court hearing. Thus, for many Muslims, they really did not need another government's initiative on marriage bill which further contradicted their religious conviction.

\footnotetext{
63 Muhammad Rashid Rida, Tafsir al-Manar, vol. 4 (Beirut: Dar al-Ma'arifah, n.d.), pp. 344-349.

64 The hadith was narrated Abu Huraira: The Prophet said, "A virgin should not be married till she is asked for her consent; and the matron should not be married till she is asked whether she agrees to marry or not." See, Muslim ibn al-Hajjaj al-Naysaburi, Sabih Muslim, Vol. 2 (Jakarta: Dar al-Kutub al-Arabiyya,n.d.), pp. 593-594.

65 Rofiq, Hukum Islam di Indonesia, pp, 73-75, 321.

${ }^{66}$ Cammack, Bedner, and van Huis, "Democracy, Human Rights and Islamic Law, p. 9
} 


\section{Political context and legal ideology of Counter Legal Draft-KHI}

After the collapse of the new order regime with the resignation of President Suharto in 1998 following Asian financial crisis, another episode on the dynamics of Islamic law was unfolded. The period which later dubbed Era Reformasi was proven to bring mixed results to the legislation of Islamic law in Indonesia. Before dwelling more about this issue, Era Reformasi was not simply about regime change. It was more than that since it marked the shift from authoritarian regime to democracy along with its bells and whistle. It brought back free speech, reasonably free and fair election, new commitment to law enforcement, and substantial effort of corruption eradication. In the early days of Era Reformasi, printed as well as online media mushroomed, numbers of political parties emerged beyond imagination. Islamic public discourse and practice also was prevalent unprecedented. Suddenly, thus era uncovered another Islamic thought which were undercover during the authoritarian regime of New Order. While previously public witnessed Islam though faces of modernists, traditionalists, and a few liberals, this Era Reformasi was marked by the emergence of other types of Islam, the conservatives. ${ }^{67}$

Before discussing the conservatives, let's talk briefly about modernist Muslims. Modern Islam, a version which offered the compatibility Islam and modernity, dominated Islamic discourse during the later period of the New Order regime, especially since late 1980s onward. It is because Muslims started to accept political establishment of the New order regime to implement Islamic causes and President Suharto started to court Muslims for political support. Since the slogan of the regime was economic development and modernism, Muslims danced with it. Virtually all Muslim communities cooperated with the regime, for instance through acceptance of Pancasila as philosophical foundation of all social organizations (Asas Tungal Pancasila) in 1984, ${ }^{68}$ abandonment of political Islam, ${ }^{69}$ and toleration of some debatable

${ }^{67}$ Martin van Bruinessen refers conservative to all thoughts that reject modern, liberal or progressive interpretation to Islam, and hold firmly the established doctrines. See, Martin van Bruinessen, "Pengantar: Perkembangan Kontemporer Islam Indonesia dan 'Conservative Turn' di Awal Abad ke-21," Moch. Nur Ikhwan et.al, Conservative Turn: Islam Indonesia dalam Ancaman Fundamentalisme (Bandung: Mizan, 2014), p. 34.

68 Faisal Ismail, Ideologi Hegemoni dan Otoritas Agama: Wacana Ketegangan Kreatif Islam dan Pancasila (Yogyakarta: Tiara Wacana, 1999).

${ }^{69}$ Fachry Ali and bachtiar Effendi, Merambah Jalan Baru Islam Rekonstruksi Pemikiran Islam Indonesia Masa Orde Baru (Bandung: Mizan, 1986), p. 159. 
regime's programs, such as family planning ${ }^{70}$ and national lottery. ${ }^{71}$ Islamic higher education institutions also campaigned modern versions of Islam, especially after many students of Islamic studies graduated from western universities and returned to IAINs and taught Islam from western perspectives. They related their Islamic tradition with discourses of democracy, human rights, pluralism, and gender equality. These issues became daily staple of IAIN Students, especially in graduate levels. Since then on, modern understanding of Islam spread across the archipelago though IAINs. They, in turn, also transformed outlook and direction of Ministry of Religious Affairs, including in the area of Islamic legislation. Thus, elements of modernism then were widely upheld by bureaucrats or academic-bureaucrats in the ministry, especially in its Jakarta headquarter. In addition, Islam-based nongovernment organizations were set up by young Muslims, mostly graduated from IAINs, promoting compatibility of Islam and modernism, advocating democracy, human rights and gender equality, and offering alternative Islamic discourse. All of these were conducted by liberally and progressively reinterpreting Islamic teachings. ${ }^{72}$ Notable Islamic NGOs of this kind is P3M, Lakpesdam, LKiS, Fahmina, Puan Amal Hayati, and Rahima. ${ }^{73}$ Interestingly, many of these NGOs affiliated to traditional Muslim organization of Nahdlatul Ulama. ${ }^{74}$

On the other hand, Muslims who insist that Islam should be implemented as it was revealed in the Quran and hadith are the conservatives. In the area of Islamic law, they urge the implementation

\footnotetext{
70 Abdullahi Ahmed An-Na'im, Islam and the Secular State: Negotiating the Future of Shari'a (Cambridge, Massachusetts and London: Harvard University Press, 2008), p. 232.

71 R. William Liddle, "The Islamic Turn in Indonesia: A Political Explanation," The Journal of Asian Studies 55, 3 (August 1996), p. 614.

${ }^{72}$ Fuad Jabali and Jamhari, LAIN dan Modernisasi Islam di Indonesia (Jakarta: Logos, 2002), pp. 147-148.

73 van Bruinessen, "Selayang Pandang Organisasi, Sarikat, dan Gerakan Muslim di Indonesia," Ahmad Baiquni (ed.), Conservative Turn: Islam Indonesia Dalam Ancaman Fundamentalisme (Bandung: Mizan, 2014), pp. 74-79.

74 The seed of shift of religious discourse within nahdaltul Ulama grew since late the 1980s with the emergence of some progressive ulama, namely Adurrahman Wahid, Musthofa Bisri and Masdar F. Mas'udi, For further account for the origin and emergence of this trend, read Martin van Bruinessen, NU: Tradisi, Relasi-relasi Kuasa dan Pencarian Wacana Baru (Yogyakarta: LKiS, 1994), especially Chapter 7 and 8, pp. 207257.
} 
of Islamic law for Muslims to a degree that the conservatives differ from one to another. What they mean by Islamic law is the one stipulated in the sacred sources of Islam without alteration nor modification. Any inconsistency to the words of the Quran or hadith is deemed not Islamic, and therefore should be rejected. Admittedly, this conservatism, is shared by certain elements of mainstream Muslims within Muhamamdiyah, Nahdlatul Ulama and Majelis Ulama Indonesia. Yet, it is clearly manifested in newly established Islamic mass organizations such as Front Pembela Islam (FPI - Defender Front of Islam), ${ }^{75}$ Majelis Mujahidin Indonesia (MMI - Indonesian Council of Fighters), ${ }^{76}$ and later Hibut Tahrir Indonesia (HTI - Indonesian chapter of Hizb al-Tahrir). ${ }^{77}$ Some newly Islamic political parties also voiced this version of Islam, notably Partai Keadilan Sejahtera (PKS Justice and prosperous party) and Partai Bulan Bintang (PBB - Star and Crescent Party). ${ }^{78}$ In addition, literal interpretation of sacred sources is also apparent among salafi Muslims who are inspired by Wahhabi teaching. ${ }^{79}$

In the reform era, these two streams of Islam collide. They wrestle virtually in all issues relating to Islam, and Islamic law in particular, from the issue of rituals to politics. When in 2004, the Gender mainstreaming working group within the Ministry of Religious Affairs publicly released the CLD KHI (Counter legal Draft for Kompilasi Hukum Islam), it instantly became another battle field. CLD KHI originated when the ministry intended to replace the 1991 Compilation of Islamic Law for two purposes. It would revise certain stipulations of the Compilation which were considered irrelevant and improve the legality so that it would became an act or statute. For the purpose, the Directorate of Religious Judiciary within the Ministry of Religious

75 van Bruinessen, "Selayang Pandang Organisasi, Sarikat, dan Gerakan Muslim, p. 65

76 Martin van Bruinessen, "Pengantar Perkembangan Kontemporer Islam Indonesia 'Conservative Turn' di Awal Abad Ke-21,' Ahmad Baiquni (ed.), Conservative Turn: Islam Indonesia Dalam Ancaman Fundamentalisme (Bandung: Mizan, 2014), p. 27.

77 van Bruinessen, "Selayang Pandang Organisasi, Sarikat, dan Gerakan Muslim di Indonesia,', pp. 64-65.

78 Ahmad Baiquni (ed), Conservative Turn: Islam Indonesia Dalam Ancaman Fundamentalisme (Bandung: Mizan, 2014), p. 330.

79 Noorhaidi Hasan, "The Salafi Madrasas of Indonesia," Farish A. Noor, Yoginder Sikand and Martin van Bruinessen (eds), The Madrasa in Asia: Political Activism and Transnational Linkages (Amsterdam: ISIM/Amsterdam University Press, 2008), pp. 248249. 
Affairs set up a committee called Badan Pengkajian dan Pengembangan Hukum Islam (BPPHI - Institution for Studying and Developing Islamic Law)." The task of BPPHI is to study and develop the kompilasi which later to be enacted as an Act or Statute to give an imposing authority. ${ }^{80}$ So far, there was no clear direction concerning the ideology that underpinned the process unless some findings from Islamic judiciary that certain judges rarely cited KHI for their court decisions because of its confessional stance. ${ }^{81}$ Some conservative and traditional Muslims surely demanded more confessional version of the Compilation, namely acknowledgment of talaq outside court hearing and clear stipulation of the legality of unregistered religious marriage. ${ }^{82}$ However, BPPHI's initial conference highlighted the need of amendment of the Compilation by proposing, among other things, compulsory marriage registration, increase of marital age, and mutual responsibility of spouses. Feminists attending the seminar added much more for the draft, such as banning polygyny altogether and permission of inter-religious marriage. ${ }^{83}$ Judging from the preliminary study and the seminar, it is clear that the direction of the Compilation was not towards confessional version of Islamic family law, it promoted feminist cause, instead.

Interestingly, although it was BPPHI that was in charge of preparing the Draft, another team, that was the Gender mainstreaming working group within the ministry, came up with a draft. This was named as CLD KHI. Out of blue, on $4^{\text {th }}$ of September 2004, without much consultation to wide audience, it was revealed. ${ }^{84}$ The head of this committee was a well-known Muslim feminist close to Jaringan Islam Liberal (JIL - Liberal Islam Network) named Siti Musdah Mulia, who is a researcher at the Research and Development Institute of the Ministry of Religious Affairs. ${ }^{85}$ The members of her team were mainly

80 Nurlaelawati, Modernization, Tradition and Identity, pp. 123-124.

81 Ibid., p. 178.

82 Ibid., p. 118-122

83 Ibid., p. 123-124

84 Ibid., p. 126-127

85 She was born from a devout Muslim family in Bone, South Sulawesi. After finishing his primary education in pesantren and madrasah, she studied Islam in IAIN Alaudin Makassar. She moved to Jakarta to pursue master and doctorate degree on Islamic thoughts at IAIN Syarif Hidayatullah Jakarta. She attended overseas courses on democracy, human rights and gender in the 2000s. she was affiliated to Fatayat then to 
progressive Muslims from various background. ${ }^{86}$ Some were bureaucrats, scholars with background of Muhammadiyah, Nahdlataul Ulama and MUI, Muslim scholars from IAINs, and some activists of NGOs. In addition, there were active contributors for the draft, which were activists of NGOs, feminists, progressive ulama, and academics. ${ }^{87}$ Considering the team preparing the CLD KHI, it is not a surprise that the result reflected feminist causes. The draft did not require marriage guardian for women, allowed women to act as marriage witness, improved marital age to 19 years old for both parties, acknowledged equal responsibility of husband and wife, introduced temporary marriage, permitted inter-religious marriage, prohibited polygyny, gave rights of nushur (disobedience), ibdad (mourning period), and ruju' (reconciliation) to husband and wife. 88 There are more to this which sharply contradicted to Islamic jurisprudence. The team concluded these stipulations by employing unconventional approach to Islamic law of maslahah, maqasid al-shari'ah, public reason and local wisdom in reading the texts of the Quran and hadith. The context set by the team was national and global context. By the time of its inception, National Constitution had been amended in which human rights equality and democracy were highly emphasized. Too, Indonesia had ratified

Muslimat of Nahdlatul Ulama, two women organization of Nahdlatul Ulama. She is chairman of ICRP (Indonesian Conference On Religion and Peace). She is trainer and resource person in workshops and conference on gender, human rights as well as prolific writer on Islamic subjects, especially in gender issues. For further detail, see her official website entitled Mujahidah Muslimah, http://www.mujahidahmuslimah.com/ home/index.php/profil/musdah-mulia/113-biografi-musdah-mulia.

86 Her team included Marzuqi Wahid (a lecturer of IAIN Nurjati Cirebon and activist affiliated to NU), Abdul Muqsith Ghozali (a young progressive scholar of Nahdlatul Ulama), Aniq Farida, Saleh Paraonan Daulay (a young intellectual of Muhammadiyah), Ahmad Suaedy (an activist of Wahid Instutute and Lakpesdam NU), Marzani Anwar (a muslim scholar from UIN Sunan Kalijaga Yogyakarta and active in women empowerment projects in the Ministry of Religious Affairs), Abdurrohman Abdullah, Ahmad Mubarok (muslim scholar from UIN Syarif Hidayatullah Jakarta), Amirsyah Tambunan (Chairman of Muhammadiyah Youth organization), and Asep Taufik Akbar (academics from IAIN Maulana Sultaan Hasanuddin Banten). See, for instance, Marzuki Wahid, Fiqih Indonesia, (Bandung: Marja, 2014), pp. 229-231.

87 Marzuki Wahid, "Counter Legal Draft Kompilasi Hukum Islam (CLD-KHI) From The Perspective of Politics Of Law In Indonesia," paper presented at The $4^{\text {th }}$ Annual Islamic Studies Postgraduate Conference, The University of Melbourne, 17-18 November 2008), p. 49-50.

88 Ibid., pp. 47-48. 
CEDAW (Convention on Elimination of all Forms of Discrimination against Women), enacted Act No. 39/1999 on Human Rights, Act No. 23/2002 on Child Protection, and Act No. 23/2004 on the Elimination of Domestic Violence. It was under this context that CLD KHI was formulated. ${ }^{89}$

Thus, it is understandable that although its authors insisted that CLD KHI was a result of reinterpretation of Islamic teaching, albeit progressively, ${ }^{90}$ the departure from traditional Islamic family law was radical. This promptly triggered fierce reactions from many Muslims, from moderates to conservatives. ${ }^{91}$ Fauzan al-Anshari, the spokesperson of Majelis Mujahidin Indonesia (MMI - Council of Indonesia Muslim Fighters), a conservative group once led by $\mathrm{Abu}$ Bakar Baasyir, protested the CLD KHI to the Minister of Religious Affairs arguing that it was contradictory to Islam and might result in fitna (grave consequence). ${ }^{92}$ Similarly, HTI, through its women movement also expressed its rejection arguing that CLD would destroy Islamic family law and Islamic family altogether. ${ }^{93}$

Moderate academics and ulama, both from modern persuasion like Muhammadiyah and traditional inclination like Nahdlatul Ulama also expressed their opposition on CLD KHI. ${ }^{94}$ MUI, through its Secretary General who was also the chairman of Muhammadiyah, Din Syamsuddin, stated that this CLD KHI contained many bid'a

89 Marzuki Wahid, "The Discourse of Indonesian Fiqh: Methodological Bid of Family Law Reform," Al-Mawarid: Journal of Islamic Law XV, 1 (August 2015), pp. 156-157.

90 Ibid., p. 156.

91 Thus, the dimension of debates has shifted from what happened surrounding Marriage Act in the 1970s between secular nationalists and Catholics in one side against Muslims on another. This time though, the debate concerning CLD-KHI was more between progressive Muslims in one side and moderate as well as conservative Muslims in the other. Read, Nur Kholis Setiawan and Djaka Soetapa, Meniti kalam kerukunan: beberapa istilah kunci dalam Islam dan Kristen, Volume 1 (Jakarta: BPK Gunung Mulia, 2010), p. 258.

92 Masdar Hilmy, Islamism and Democracy in Indonesia: Piety and Pragmatism (Singapore: ISEAS, 2010), p. 238.

93 Ita Musarrofa, "Respon Muslimah Hizbuttahrir Indonesia (MHTI) terhadap Rancangan dan Undang-Undang terkait Perempuan dan Keluarga," Jurnal Al-Qalam 21, 1 (June 2015), p. 155.

94 Although admittedly, many progressive Muslims drafting the CLD KHI had close link to Nahdlatul Ulama, namely Siti Musdah Mulia, Marzuki Wahid, A. Moqsith Ghozali, and Ahmad Suaedy. 
(innovation). Huzaimah Tahido Yanggo, an al-Azhar graduate, a Professor of Islamic law from IAIN Syarif Hidayatullah Jakarta, and member of fatwa council of MUI and Nahdlatul Ulama wrote that CLD KHI is contradictory to the Quran, hadith and other authoritative sources of Islamic law which are product of interpretation by Muslim jurists (fuqaba-mujtabidin). The drafters of CLD KHI had located the texts of the Quran and hadith under the superiority of reason and social condition as well as reduced the texts according only to their purposes. They also believed that traditional Islamic jurisprudence had been out of date and out of context and therefore should be abandoned. The religious paradigm in the draft had shifted from theocentric to anthropocentric which prioritized human being over the will of God. As a result, it is a destructive and deviant innovation, not at all a renewal of Islamic law, made by liberals and admirers of Western values of democracy and secularism, to say the least. ${ }^{95}$ Similarly, her colleague, Ali Yafie, another ulama affiliated to Nahdlatul Ulama and MUI, stated his opposition to CLD KHI by saying that it CLD KHI does not apply the systematic methods and maxims (of usul al-figh) in implementing Islamic law for the sake of adopting Western principles. Instead, it employed certain parts of the usul al-fiqh eclectically. ${ }^{96}$ Likewise, in his book, Marzuki Wahid, one of the author of CLD KHI, reported opposition of traditional ulama affiliated to Nahdlatul Ulama about the draft, namely by Mas Subadar, a senior ulama in East Java who stated that it was imperative for Muslims to ignore CLD KHI. ${ }^{97}$

In short, the publication of CLD KHI had instigated not just controversy but also unrest and even animosity. In one of his remarks, Muhammad Maftuh Basyuni, the Minister of Religious Affairs at the time stated that the main task of his ministry was to maintain religious harmony. This CLD KHI had ruined that because it was proposed many thoughts that were contradictory to mainstream Islamic law believed and practiced by Indonesian Muslims. He was unbelievably stunned how a bunch of people right under his nose had created such

\footnotetext{
95 Huzaemah Tahido Yanggo, "Kontroversi Revisi Kompilasi Hukum Islam (KHI) dalam Perspektif pembaharuan Hukum Islam di Indonesia," Zaitunah Subhan (ed.), Membendung Liberalisme (Jakarta: Republika, 2005), pp. 1-5.

96 Ali Yafie, "Apa yang Ada di Balik Pembaharuan Hukum Islam ala CLD-KHI," Zaitunah Subhan (ed.), Membendung Liberalisme (Jakarta: Republika, 2005), p. 75.

97 Wahid, Fiqib Indonesia, pp. 249-251.
} 
commotion. Thus, he did not only suspend the draft but cancelled it altogether. There would not be initiation to discuss the CLD KHI in the legislature, period. ${ }^{98}$ At the end, a combination of democratic and free speech environment, protests from Muslims of virtually all persuasions, and the overtly progressive nature of the CLD KHI has killed an effort to liberalize the Compilation of Islamic law.

\section{Conclusion}

The process of modernization of Islamic family have been taking place in Muslim world. From lesson learned elsewhere, it always involves reinterpretation of Islamic law in one way or another, adoption of doctrines from various schools of law, and sometimes strong role of the state. In Indonesia, initial legislation process in the 1970s had resulted in the 1974 Marriage Act. When the draft was mainly secular, the product was a combination of secular demand and Islamic flavor. Afterwards, Muslims had to come to term to digest what they got in the Act and come up with creative justification to appease their religious conviction. The 1991 Compilation of Islamic law was in fact a part of this justification although the main purpose was to provide legal basis for judges of Religious court when delivering verdicts. At the same time, it tried, and partially successful, to introduce certain degree of legal change. The key of its success was the careful calculation of key figures in navigating the course of the Compilation project and the full support, both politically and financially, from the most powerful man in the country, President Suharto. They reached out to the Ulama, academics, studying relevant treatises of Islamic jurisprudence, and other necessary steps that ensuring the sanctioning of the Compilation.

CLD-KHI, on the other hand, featured plenty stuffs for which its failure was a matter of inevitability. It was not supported by friendly political atmosphere since the democratic climate of the reform era demanded free speech and public participation. Working under the radar, like the gender mainstreaming team within Ministry of Religious Affairs did when writing the CLD-KHI would not work. Moreover, some segments of Indonesian Muslims had become more conservative by the time this progressive CLD-KHI was launched. They who would shout loudly at any ideas that cause discomfort to their religious sense.

98 Muhammad Maftuh Basyuni, "Sambutan Menteri Agama RI," Zaitunah Subhan (ed.), Membendung Liberalisme (Jakarta: Republika, 2005), pp, viii-ix. 
However, the deathblow of the CLD-KHI was actually its liberal stance on family law. Although Islamic legal reasoning remained employed, it was used progressively. This ignited reaction not only from the conservatives, but moderates alike, be they traditional or modernist Muslims. Promptly, the CLD-KHI was terminated and never discussed for legislation purposes except in academic pages. []

\section{References}

\section{Books and Articles}

Ahmad, Amrullah et.al. Dimensi Hukum Islam dalam Sistem Hukum Nasional: Mengenang 65 tabun Prof. Dr. H. Busthanul Arifin, SH. Jakarta: Gema Insani Press, 1996.

Ali, Fachry and bachtiar Effendi. Merambah Jalan Baru Islam Rekonstruksi Pemikiran Islam Indonesia Masa Orde Baru. Bandung: Mizan, 1986.

Ali, Mohammad Daud. Asas-asas Hukum Islam. Jakarta: Rajawali Press, 1990.

Anderson, J.N.D. Islamic Law in the Modern World. New York: New York University Press, 1959.

-. "The Significance of Islamic Law in the World Today". The American Journal of Comparative Law, 9, 2 (Spring 1960).

An-Na'im, Abdullahi Ahmed. Islam and the Secular State: Negotiating the Future of Shari'a. Cambridge, Massachusetts and London: Harvard University Press, 2008.

Arifin, Busthanul. Pelembagaan Hukum Islam di Indonesia: Akar Sejarah, Hambatan dan Prospeknya. Jakarta: Gema Insani Press, 1996.

Basyuni, Muhammad Maftuh. "Sambutan Menteri Agama RI". Zaitunah Subhan (ed.). Membendung Liberalisme. Jakarta: Republika, 2005.

Billoo, Yasir. "Change and Authority in Islamic Law: The Islamic Law of Inheritance in Modern Muslim States". ExpressO Preprint Series (2003), paper 12.

Baiquni, Ahmad (ed.). Conservative Turn: Islam Indonesia Dalam Ancaman Fundamentalisme. Bandung: Mizan, 2014. 
Buehler, Michael. The Politics of Shari'a Law: Islamist Activists and the State in Democratizing Indonesia. Cambridge: Cambridge University Press, 2016.

Cammack, Mark, Adriaan Bedner, and Stijn van Huis. "Democracy, Human Rights and Islamic Law in Post-Soeharto's Indonesia”. New Middle Eastern Studies, 5 (2015).

Cammack, Mark. "Indonesia's 1989 Religious Judicature Act: Islamization of Indonesia or Indonesianization of Islam?”. Arskal Salim and Azyumardi Azra (ed.). Shariah and Politics in Modern Indonesia. Singapore: ISEAS, 2003.

Coulson, Noel J. A History of Islamic Law. Edinburgh: Edinburgh University Press, 1964.

Crone, Patricia and Martin Hinds. God's Caliph: Religious Authority in the First Century of Islam. Cambridge: Cambridge University Press, 1986.

Galanter, Marc. "Justice in Many Rooms: Courts, Private Ordering and Indigenous Law”. Journal of Legal Pluralism, 19 (1981).

Hallaq, Wael B. A History of Islamic Legal Theories: An Introduction to Sunni Usul al-fiqh. Cambridge: Cambridge University Press, 1997.

-------. Authority, Continuity and Change in Islamic Law. Cambridge: Cambridge University Press, 2001.

Hamid, Andi Tahir. Beberapa Hal Baru Tentang Peradilan Agama dan Bidangnya. Jakarta: Sinar Grafika, 1996.

Hasan, Noorhaidi. "The Salafi Madrasas of Indonesia". Farish A. Noor, Yoginder Sikand and Martin van Bruinessen (eds). The Madrasa in Asia: Political Activism and Transnational Linkages. Amsterdam: ISIM/Amsterdam University Press, 2008.

Hefner, Robert W. "Islam, State, and Civil Society: ICMI and the Struggle for the Indonesian Middle Class". Indonesia, 56 (October 1993).

--------. Civil Islam: Muslim and Democratization in Indonesia. Princeton: Princeton University Press, 2000.

Hilmy, Masdar. Islamism and Democracy in Indonesia: Piety and Pragmatism. Singapore: ISEAS, 2010. 
Hodgson, Marshal G.S. The Venture of Islam. vol. 1. Chicago: The University of Chicago Press, 1977.

Hooker, MB. Indonesian Islam: Social Change Through Contemporary Fatawa. Crows Nest: Allen and Unwin, 2003.

Idri. 'Religious Court In Indonesia: History and Prospect". Journal of Indonesian Islam, 3, 2 (December 2009).

Ismail, Faisal. Ideologi Hegemoni dan Otoritas Agama: Wacana Ketegangan Kreatif Islam dan Pancasila. Yogyakarta: Tiara Wacana, 1999.

Jabali, Fuad and Jamhari. IAIN dan Modernisasi Islam di Indonesia. Jakarta: Logos, 2002.

Jansen, Nils. The Making of Legal Authority. Oxford: Oxford University Press, 2010.

Kamali, Muhammad Hashim. Principles of Islamic Jurisprudence. Cambridge: Islamic Text Society, 1991.

Kersten, Carool. A History of Islam in Indonesia: Unity in Diversity. Edinburgh: Edinburgh University Press, 2017.

Lev, Daniel S. Islamic Courts in Indonesia: A Study in the Political Bases of Legal Institutions. Berkeley Los Angeles and London: University of California Press, 1972.

Liddle, R. William. "The Islamic Turn in Indonesia: A Political Explanation”. The Journal of Asian Studies 55, 3 (August 1996).

Lukito, Ratno. Pergumulan antara Hukum Islam dan Adat di Indonesia. Jakarta: INIS, 1998.

Maine, Sir Henry Sumner. Ancient Law Ancient Law, Its Connection with the Early History of Society, and Its Relation to Modern Ideas. London: John Murray, 1861.

Mahmudi, Yon. Islamising Indonesia: the rise of Jemaah Tarbiyah and the Prosperous Justice Party (PKS). Canberra: ANU E-Press, 2008.

Mayer, Ann Elizabeth. "The Shari'ah: A Methodology or a Body of Substantive Rules". Ziadeh. London: University of Washington Press, 1990.

Mukri, Barmawi. "Kedudukan dan Peranan Kompilasi Hukum Islam dalam Sitem Hukum Nasional". Jurnal Hukum, 8, 17 (June 2001). 
Musarrofa, Ita. "Respon Muslimah Hizbuttahrir Indonesia (MHTI) terhadap Rancangan dan Undang-Undang terkait Perempuan dan Keluarga". Jurnal Al-Qalam, 21, 1 (June 2015).

al-Nisaburi, Muslim ibn al-Hajjaj. Sabih Muslim, Vol. 2. Jakarta: Dar alKutub al-Arabiyya, n.d.

Nizam, Shaikh and 'Ulama' al-Hind al-'Alam. al-Fatawa al-'Alamkiriyah al-Ma'rufah bi al-Fatawa al-Hindiyyah, edited by Ghulam Nabi Tunsawi. 6 volume. Kuitiyah: Maktabah Majidiyah, 1983.

Nurlaelawati, Euis. Modernization, Tradition and Identity: The Kompilasi Hukum Islam and Legal Practice in the Indonesian Religious Courts. Amsterdam: ICAS/Amsterdam University Press, 2010.

Onar, S.S. "The Majallah". Majid Khaddury and Herbert J. Liebesny (eds). Law in the Middle East: Origin and Development of Islamic Law. Washington D.C.: The Middle East Institute, 1955.

Rahman, Fazlur. "A Survey of Modernization of Muslim Family Law". International Journal of Middle East Studies, 11, 4 (July 1980).

Rabi', Ibrahim Abu (ed.). Blackwell Companion to Contemporary Islamic Thought. Malden, Oxford and Carlton: Blackwell Publishing, 2006.

Rida, Muhammad Rashid. Tafsir al-Manar, Vol. 4. Beirut: Dar alMa'arifah, n.d.

Rofiq, Ahmad. Hukum Islam di Indonesia. Jakarta: RajaGrafindo Persada, 1995.

Salim, Arskal. Challenging the Secular State: The islamization of Law in Modern Indonesia. Hawai'i: University of Hawai'i Press, 2008.

Siddiq, Mazheruddin. the Introduction of Muwatta' Imam Malik book, transl. by Muhamad Rahimuddin. New Delhi: Bhavan Book, 1989.

Schacht, Joseph. "Foreign Elements in the Ancient Islamic Law". Journal of Comparative Legislation and International Law 32 (1950).

-------. Introduction to Islamic Law. Oxford: Clarendon Press, 1986.

Schofield, Philip and Jonathan Harris (eds.). The Collected Works of Jeremy Bentham: Legislator of the World: Writings on Codification, Law and Education. Oxford: Clarendon Press, 1988.

Scott, Kyle A. "A Platonic Critique of Codification". Journal Jurisprudence, 159 (2009). 
Setiawan, Nur Kholis and Djaka Soetapa. Meniti Kalam Kerukunan: Beberapa Istilah Kunci dalam Islam dan Kristen, Vol 1. Jakarta: BPK Gunung Mulia, 2010.

Syarifuddin, Amir. Hukum Perkawinan Islam di Indonesia. Jakarta: Kencana, 2006.

Thalib, Sayuti. Hukum Kekeluargaan Indonesia: berlaku Untuk Umat Islam. Jakarta: UI Press, 1986.

Tresna, R. Peradilan di Indonesia Dari Abad Ke Abad. Jakarta: Pradnya Paramita, 1978.

van Bruinessen, Martin. "Kurdish 'Ulama and their Indonesian disciples". Les annals de l'autre Islam 5 (1998).

---------. "Pengantar: Perkembangan Kontemporer Islam Indonesia dan 'Conservative Turn' di Awal Abad ke-21'. Moch Nur Ikhwan et.al. Conservative Turn: Islam Indonesia dalam Ancaman Fundamentalisme. Bandung: Mizan, 2014.

---------. 'Selayang Pandang Organisasi, Sarikat, dan Gerakan Muslim di Indonesia". Ahmad Baiquni (ed.). Conservative Turn: Islam Indonesia Dalam Ancaman Fundamentalisme. Bandung: Mizan, 2014.

--------. NU: Tradisi, Relasi-relasi Kuasa dan Pencarian Wacana Baru. Yogyakarta: LKiS, 1994.

Wahid, Marzuki. Counter Legal Draft Kompilasi Hukum Islam (CLD-KHI) From The Perspective Of Politics Of Law In Indonesia. Paper presented at The $4^{\text {th }}$ Annual Islamic Studies Postgraduate Conference, The University of Melbourne, 17-18 November 2008.

-. Fiqib Indonesia. Bandung: Marja, 2014.

--. "The Discourse of Indonesian Fiqh: Methodological Bid of Family Law Reform". Al-Mawarid: Journal of Islamic Law, XV, 1 (August 2015).

Yafie, Ali, “Apa yang Ada di Balik Pembaharuan Hukum Islam ala CLD-KHI”. Zaitunah Subhan (ed.). Membendung Liberalisme. Jakarta: Republika, 2005.

Yanggo, Huzaemah Tahido. "Kontroversi Revisi Kompilasi Hukum Islam (KHI) dalam Perspektif pembaharuan Hukum Islam di Indonesia". Zaitunah Subhan (ed.). Jakarta: Republika, 2005. 


\section{Internet Sources}

DetikNews, "Lika-liku Draf RUU Nikah Siri Hingga Jadi Misterius". https://news.detik.com/berita/d-1303144/lika-liku-draf-ruunikah-siri-hingga-jadi-misterius/komentar, $19^{\text {th }}$ of February 2010.

Mujahidah Muslimah, http://www.mujahidahmuslimah.com/home/index.php/profil/musdah-mulia/113-biografi-musdah-mulia.

Sjafei, Edy Supriatna, Kontroversi Pidana Pelaku Nikah Siri, https://megapolitan.kompas.com/read/2010/02/24/00141637 Lkontroversi.pidana.pelaku.nikah.siri?page $=$ all, Kompas.com, $24^{\text {th }}$ of February 2010. 